\title{
The EUROCET Network: Support for Coding, Vigilance and Surveillance
}

\author{
Maura Mareri Marzia Filippetti Angelo Ghirardini Francesca Vespasiano Paola Di Ciaccio \\ Alessandro Nanni Costa
}

Italian National Transplant Centre, Rome, Italy

\begin{abstract}
Keywords
Data management system - Donors - Haematopoietic cell transplantation - Haematopoietic stem cells .

Quality management - Stem cell collection - Storage .

Transplantation
\end{abstract}

\section{Summary}

Background: In the last years, there have been increasing concerns about the safety and traceability of human tissues and cells in Europe. In order to regulate this part of medical practice, the European Commission issued 3 directives between 2004 and 2006 and endorsed EUROCET to support member states in fulfilling some of their obligations. Methods: EUROCET created a connection with the European Union (EU) Competent Authorities (CAs) and set up a website where lists of the CAs, the authorized Tissue Establishments (TEs) and the activity data are published and updated. Moreover, EUROCET is involved within the Vigilance and Surveillance of Substances of Human Origin (SOHO V\&S) project, aiming to support the EU member states in the establishment of vigilance and surveillance systems for tissues and cells. EUROCET is also working with EU stakeholders to develop a common coding system concerning donation and products. Results: There are 33 countries in EUROCET and 57 CAs. 3,974 TEs are recorded: 1,108 for tissues, 1,480 for haematopoietic progenitor cells and 1,386 for assisted reproduction. On the website, it is possible to find the 2010 activity data report. Conclusion: Based on its cooperation with the CAs, EUROCET represents them in the European network. Nowadays, the EU member states can rely on a web portal and database in order to put the tissue and cell directives into practice.

\author{
Schlüsselwörter \\ Datenmanagementsystem · Spender · Hämatopoetische \\ Zelltransplantation - Hämatopoetische Stammzellen . \\ Qualitätsmanagement · Stammzellsammlung · Speicherung · \\ Transplantation
}

\section{Zusammenfassung}

Hintergrund: In den letzten Jahren gab es in Europa zunehmende Bedenken hinsichtlich der Sicherheit und Nachverfolgbarkeit von menschlichen Geweben und Zellen. Um diesen Teil der medizinischen Praxis zu regulieren, wurden von der Europäischen Kommission zwischen 2004 und 2006 drei Direktiven angefertigt und die EUROCET dahingehend unterstützt, die Mitgliedsstaaten bei der Erfüllung einiger ihrer Verpflichtungen zu unterstützen. Methoden: EUROCET rief eine Anbindung der zuständigen Behörden der Europäischen Union (EU) ins Leben und entwickelte eine Website, auf der Listen der zuständigen Behörden und der autorisierten Gewebeinstitutionen sowie die Aktivitätsdaten publiziert und aktualisiert werden. Darüber hinaus ist EUROCET in das "Vigilance and Surveillance of Substances of Human Origin»(SOHO V\&S)-Projekt involviert, das darauf abzielt, die EU-Mitgliedsstaaten bei der Entwicklung von Vigilanz- und Überwachungssystemen für Gewebe und Zellen zu unterstützen. EUROCET arbeitet außerdem mit EU-Interessensvertretern zusammen, um ein einheitliches Kodierungssystem für Spenden und Produkte zu entwickeln. Ergebnisse: In EUROCET sind 33 Länder und 57 zuständigen Behörden organisiert. 3974 Gewebeinstitutionen sind registriert: 1108 für Gewebe, 1480 für hämatopoetische Vorläuferzellen und 1386 für unterstützte Reproduktion. Auf der Website findet sich der aktuelle Aktivitätsdatenreport 2010. Schlussfolgerung: Basierend auf der Kooperation mit den zuständigen Behörden, repräsentiert EUROCET diese innerhalb des europäischen Netzwerks. Heutzutage können die EU-Mitgliedsstaaten auf ein Webportal und eine Datenbank zurückgreifen, um die Gewebeund Zelldirektiven in der Praxis umzusetzen.

\begin{tabular}{ll}
\hline KARGER & ( ) 2011 S. Karger GmbH, Freiburg \\
Fax +497614520714 & Accessible online at: \\
Information@Karger.de & www.karger.com/tmh \\
www.karger.com &
\end{tabular}

Dr. Alessandro Nanni Costa 


\section{Introduction}

Nowadays, Tissue Establishment (TE) testing, processing, preservation, storage, or distribution of human tissues and cells intended for human application have become part of the health system of the European Union (EU). Achievements in tissue and cell transplantation have permitted to reach improved results in terms of cure and quality of life for patients suffering from diseases that were incurable before the advent of transplant medicine; however, there have been rising concerns about the quality, safety and traceability of these substances in European countries. In order to regulate this emerging part of medical practice, the European Commission (EC) issued 3 directives between 2004 and 2006: The first one (2004/23/EC) pointed to 'Setting standards of quality and safety for the donation, procurement, testing, processing, preservation, storage and distribution of human tissues and cells' [1]; the second one (2006/17/EC) developed 'Certain technical requirements for the donation, procurement and testing of human tissues and cells' [2]; the third one (2006/86/ EC) implemented 'Traceability requirements, notification of serious adverse reactions and events and certain technical requirements for the coding, processing, preservation, storage and distribution of human tissues and cells' [3]. To help member states (MS) fulfil specific obligations, such as the establishment of a network linking the national TE registers (23/2004/EC: art. 10.2 and 10.3), the EC endorsed EUROCET ('The European Network of Competent Authorities for Tissues and Cells') to become - since the original project funded under the trans-European e-services (e-TEN) program of the EC (DG INFSO) - the registry of all national TEs and a point of reference to collect, publish and disseminate official data on tissues, haematopoietic progenitor cells (HPC) and cells for assisted reproduction (ART) (23/2004/ EC: art. 10.1). TEs and activity data have to be reported to EUROCET directly by EU Competent Authorities (CAs), which are organizations designated by the MS in charge for implementing the requirements of the Directives 23/2004, art. 4.1 and 6.1. Moreover, one of the key functions of CAs foreseen in the Directives 23/2004/EC, art. 11.1 and EC 2006/86, art. 5-8 is to introduce in each MS a comprehensive system for vigilance and surveillance (V and $\mathrm{S}$ ) on human tissues and cells for transplantation and for ART, with the reporting and investigation of serious adverse reactions/events (SAR/Es). To this purpose, EUROCET accepted to participate in the 'Vigilance and Surveillance of Substances of Human Origin' (SOHO V\&S) project (www.sohovs.org), aimed to develop a shared view of how SAR/Es in this field are reported, evaluated and investigated [4]. At last, the MS shall ensure the implementation of a donor identification system that assigns a unique code to each donation and to each of the products associated with it (23/2004/EC: art. 8 and 25), in order to guarantee traceability from the donor to the recipient and vice versa. EUROCET is working with EU stakeholders to develop a single European coding system to ensure proper identification of the donors and the traceability of all donated material and to provide information on the main characteristics and properties of the tissues and cells (EC 2006/86: art. 9-10).

\section{Material and Methods / Results}

EUROCET has become the official network of the EU national CAs for tissue and cell donation and transplantation (collecting and publishing data obtained from them) as well as the official registry of all authorized TEs. EUROCET started this work in September 2005 when the Information Society and Media Directorate-General (DG INFSO) under the e-TEN program of the EC decided to finance the original project for 3 years, aiming at setting up a registry on organ, tissue and cell donation and transplantation activities shared by old and new MS coordinated by the Italian National Transplant Centre, the Italian CA. On May 30, 2008, the CAs met in Brussels for their periodical meeting and formally endorsed EUROCET to cover these roles. Moreover, the EC encouraged the use of the EUROCET portal as a way to fulfil some of the obligations of the tissue and cell directives, e.g. according to art. 10.3 of Directive 23/2004/EC: 'MS and the Commission should establish a network linking the national tissue establishment registers', and in the draft of the first report to the Council, the EU Parliament, the EU Economic and Social Committee and the Committee of the Regions on the application of the directive, the EC states: '... Currently this network is made by EUROCET, which is a registry of national tissue establishments and activity reports managed by the Italian Competent Authority'. In order to reach its goals, EUROCET has relied on the original multilingual website (www.eurocet.org) as a powerful tool for communication and dissemination. Moreover, the team has continued to carry out strict and regular contacts with the EU national CAs and has started a collaboration with the leading scientific associations in the field of tissues and cells: the European Association of Tissue Banks (EATB), the European Group for Blood and Marrow Transplantation (EBMT), and the European Society for Human Reproduction and Embryology (ESHRE). In this way, EUROCET strives to remain continuously up to date from the scientific point of view, to disseminate data among professionals and to compare annual data reports. In particular, for HPC data collection, it has been possible to cover and complete the entire EU scenario, thanks to the mutual exchange with the EBMT, a scientific non-profit organization dedicated to the promotion of all aspects associated with HPC transplantation, including basic and clinical research, education, standardization, quality control, and accreditation of transplant procedures.

Nowadays, EU citizens and professionals can consult the website and download information on: 


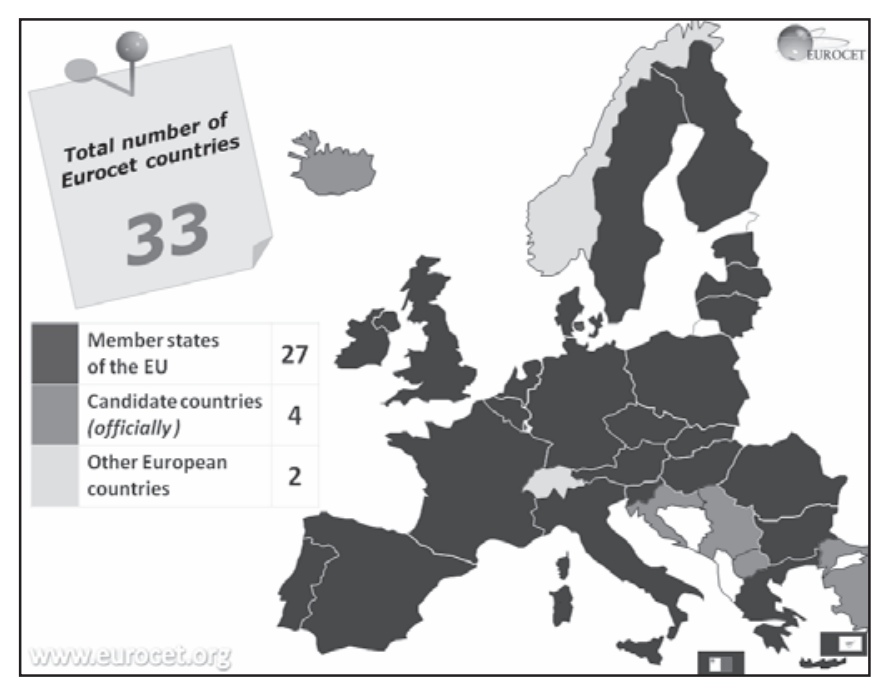

Fig. 1. Total number of EUROCET countries.

- EU national CAs for tissues and cells: There are 33 countries with a total number of 57 CAs recorded in EUROCET (fig. 1, 2). It is remarkable that every country has appointed a CA for tissues and HPC.

- Official TEs coming directly from all EU national CAs: 3,974 TEs are recorded: 1,108 for tissues, 1,480 for HPC and 1,386 for ART, with a more than threefold increase in the total number from 2008 to 2011 (fig. 3).

- Activity data on tissues, HPC, and ART donation and transplantation provided by all EU national CAs [5]. The CAs can upload their data using a specific form to be sent to a dedicated e-mail address or asking the credentials = ACCESS to the members area of the website. Data on tissues and HPC are also reported to the Newsletter Transplant of the Council of Europe for the annual publication of the 'International Figures on Donation and Transplantation' [6].

It is possible to find activity data for:

- Tissues

- annual data on donation, transplantation, processing and import-export activities of human tissues, per country;

- overall numbers of human tissue donations, presented in different categories (cadaveric and living donation) and from different origins (cornea, skin, cardiac tissues, musculoskeletal tissues and placenta);

- updated numbers of procured human tissues, presented in different categories (cadaveric and living donation) and from different origins (cornea, skin, cardiac tissues, musculoskeletal tissues and placenta);

- tissue banking activities, divided into different phases (distribution, processing and storage);

- import-export activities within the EU and in dealing with extra-EU countries;

- numbers of patients and tissues transplanted.
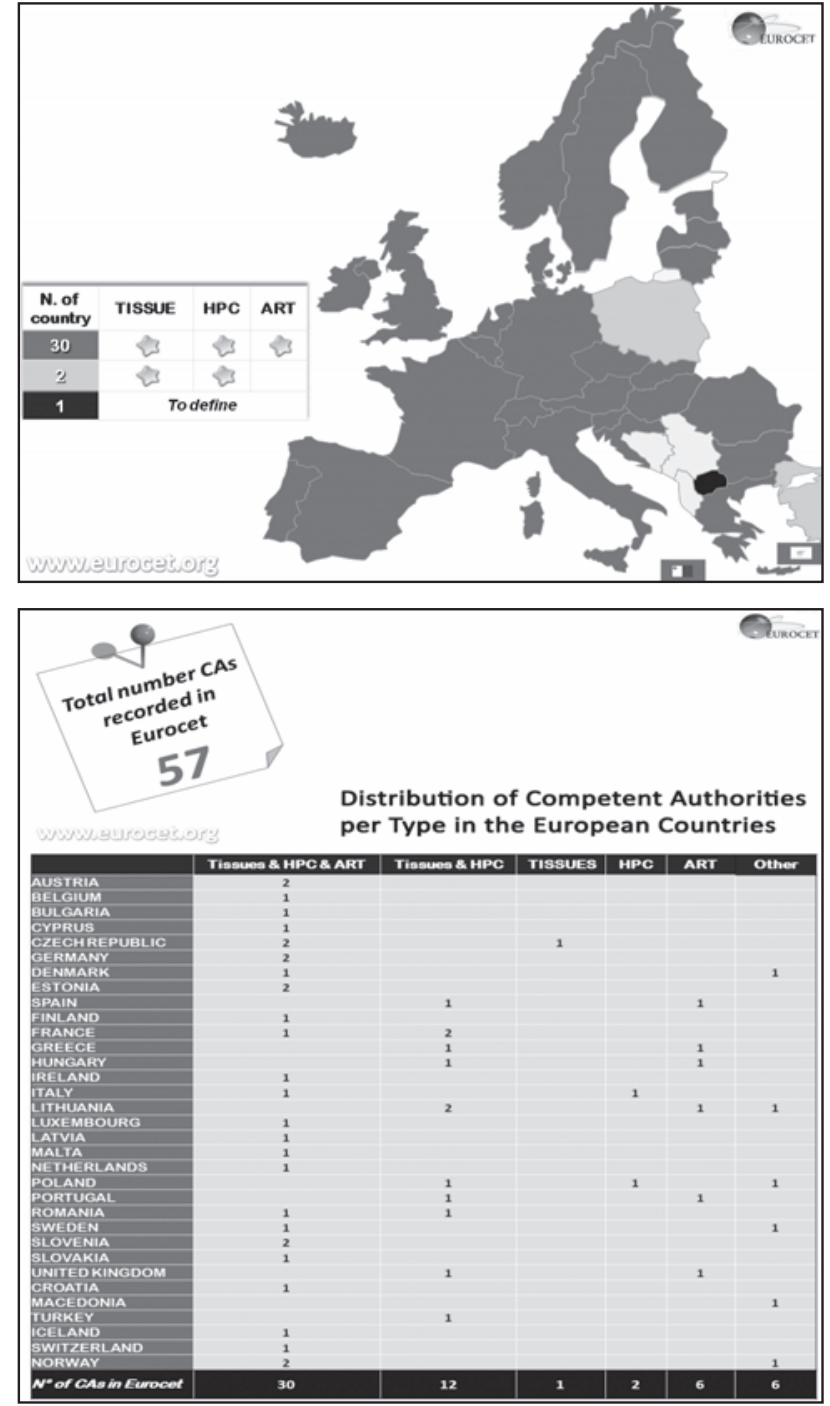

Fig. 2. EU national CAs: situation $(\mathbf{A})$ and number $(\mathbf{B})$ of CAs recorded per country.

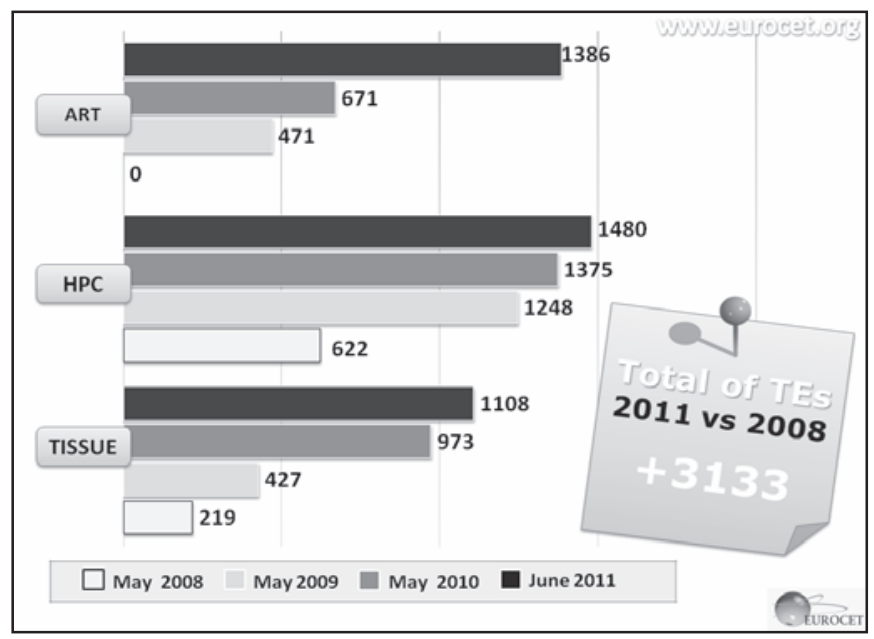

Fig. 3. Development of TE numbers recorded in EUROCET. 
Fig. 4. Operational European coding structure.

\begin{tabular}{|c|c|c|c|c|}
\hline \multicolumn{5}{|c|}{ Donation identification: } \\
\hline ISO country & \multicolumn{2}{|c|}{ TE code } & \multicolumn{2}{|c|}{ Unique donation number (local/national) } \\
\hline 2 characters & \multicolumn{2}{|c|}{$\begin{array}{l}6 \text { characters } \\
\text { (alpha-numeric) }\end{array}$} & \multicolumn{2}{|c|}{$\begin{array}{l}13 \text { characters } \\
\text { (alpha-numeric) }\end{array}$} \\
\hline \multicolumn{5}{|c|}{ Product identification } \\
\hline \multicolumn{2}{|c|}{\begin{tabular}{|l|} 
Product code \\
\end{tabular}} & \multicolumn{2}{|c|}{ Split number } & Expiry date \\
\hline \multicolumn{2}{|c|}{$\begin{array}{l}\text { 1symbol }+7 \text { characters } \\
\text { (alpha-numeric) }\end{array}$} & \multicolumn{2}{|c|}{$\begin{array}{l}3 \text { characters } \\
\text { (numbers) }\end{array}$} & $\begin{array}{l}8 \text { characters } \\
\text { (numbers) }\end{array}$ \\
\hline
\end{tabular}

- $\mathrm{HPC}$

- annual data on donation, banking and transplantation of HPC, per country;

- potential donations;

- effective donations, presented in different categories (autologous/allogeneic, related/unrelated) and from different origins (cord blood, peripheral blood and bone marrow);

- cord blood banking (available for both autologous /allogeneic banking);

- transplants, presented in different categories (autologous/allogeneic, related/unrelated) and from different origins (cord blood, peripheral blood and bone marrow);

- transplants per single transplant center.

\section{- ART}

Annual data on

- ART with partner donation per type of treatment (intrauterine insemination (IUI), in vitro fertilization (IVF) and intracytoplasmatic sperm injection (ICSI));

- ART with sperm donation;

- ART with egg donation;

- ART with embryo donation.

Another key function assigned to the CAs by the above-mentioned directives is to put in place in each MS a V and S system on tissue and cell donation or human application with the reporting and investigation of SAR/Es (23/2004/EC: art. 11.1 and EC 2006/86: Art. 5-8). SOHOV and S is a 3-year project supported by co-funding from the Department of Health and Consumer Protection of the EC and working to develop a shared view of how SAR/Es in this field are reported, evaluated and investigated. Its aim is to address the harmonization of terminology and documentation and to achieve a consensus on how information should be exchanged between EU MS, the EC, and third countries [4]. EUROCET collaborates with SOHOV and $\mathrm{S}$ in order to increase transparency through the enhancement of its online platform to incorporate $\mathrm{V}$ and $\mathrm{S}$ information (new and emerging donor risks, vigilance system reports, published articles, rapid alerts for tissues and cells, news and comments, $\mathrm{V}$ and $\mathrm{S}$ guidance, dedicated projects). Both CAs and professionals in tissue and cell transplantation and ART will benefit from easy access to information, which will help them to identify risks and areas needing particular attention for preventing and responding to SAR/Es.

Lastly, article 8 of Directive 2004/23/EC foresees that MS shall ensure the traceability at the national level, stating that all tissues and cells procured, processed, stored or distributed on their territory can be traced from the donor to the recipient and vice versa (art. 8.1), and affirming the implementation of a donor identification system that assigns a unique code to each donation and to each of the products associated with it (art. 8.2). However, Directive 2004/23/EC also recommends a traceability at the EU level within article 25 , which says: '... the Commission, in cooperation with the Member States, shall design a single European coding system to provide information on the main characteristics and properties of tissues and cells'. On February 24, 2006, the Regulatory Committee established by Directive 2004/23/EC endorsed the creation of a working group on coding, including representatives of national CAs with regard to tissues and cells, in charge of defining the main specifications of a single EU coding system. Figure 4 shows the structure and contents of the EU code as agreed by the working group during the last meeting held in January 2011. The main aims of donation identification are: to identify and localize the TE of origin of the tissues or cells and to enable forward tracing of all related human substances from the donor identified by the unique donation number. The main objectives of product identification are: to recognize the nature of the substance in terms of its main characteristics and the properties of the tissue and cells transplanted. Traceability requires two elements: a code on the label and a data set recorded by the TE, the organization performing the procurement, and the organization responsible for human application. EUROCET is working with EU stakeholders to develop the EU coding system and can provide the official lists of all national authorized TEs in Europe.

\section{Discussion}

Setting up a common registry to represent all CAs joining EUROCET was an important strategy to respond to the ur- 
gent need of a unified framework, in order to ensure the highest standard of quality and safety regarding tissue and cell procedures. Moreover, all EU and extra-EU professional operators and institutions can rely on the complete and updated databases on the EUROCET website: an official information tool accessible via internet in real time. The EUROCET website would also allow citizens to enhance their decision capability regarding access to healthcare facilities and their awareness and sensitivity towards the value of donation. This strategic approach does not point to the creation of a new European system to take over existing national systems, but to the establishment of a connection between the active national systems through common languages and communication tools: as an additional step towards the suc- cessful collaboration among the MS and as another transparent approach to the safety of the European citizens.

\section{Acknowledgements}

The EUROCET team owes a special debt of gratitude to all the CAs for their efforts dedicated to the data collection, to the EBMT for its precious collaboration in the mutual data exchange, and to the personnel at the Italian National Transplant Centre.

\section{Disclosure Statement}

The authors declared no conflict of interest.

\section{References}

1 Directive 2004/23/EC - 'Setting standards of quality and safety for the donation, procurement, testing, processing, preservation, storage and distribution of human tissues and cells'.

2 Directive 2006/17/EC - 'Implementing Directive 2004/23/EC of the European Parliament and of the Council as regards certain technical requirements for the donation, procurement and testing of human tissues and cells'

\footnotetext{
3 Directive 2006/86/EC - 'Implementing Directive 2004/23/EC of the European Parliament and of the Council as regards traceability requirements, notification of serious adverse reactions and events and certain technical requirements for the coding, processing, preservation, storage and distribution of human tissues and cells'.

4 Fehily D, Costello P, Cresvaux H, Garrido G, Noel L, O'Toole C, Smith M, Swann I, Teskrat F, Uhrynowska-Tyszkiewicz I, Nanni Costa A: Vigilance and Surveillance of Substances of Human Origin (SOHO V and S) - developing a common approach in the European Union. Blood Transplant Matters 2011;33:20-22.
}

5 Filippetti M, Ghirardini A, Mareri M, Vespasiano F, Di Ciaccio P, Nanni Costa A: Annual Eurocet report on tissue, hematopoietic progenitor cell and reproductive cell donation and transplantation activities. Organs Tissues Cells 2011;1:5-10.

6 Council of Europe: International figures on donation and transplantation - 2010. Newsletter Transplant 2011;16:47-58 